\title{
,nu \\ Natural Para Rubber in Road Embankment Stabilization
}

Salisa Chaiyaput $1, * \mathbb{C}$, Nakib Arwaedo ${ }^{2}$, Pitthaya Jamsawang ${ }^{3}$ and Jiratchaya Ayawanna ${ }^{4}$

check for

updates

Citation: Chaiyaput, S.; Arwaedo, N.; Jamsawang, P.; Ayawanna, J. Natural Para Rubber in Road Embankment Stabilization. Appl. Sci. 2022, 12, 1394 https://doi.org/10.3390/app12031394

Academic Editor: Luís

Picado Santos

Received: 30 December 2021

Accepted: 17 January 2022

Published: 28 January 2022

Publisher's Note: MDPI stays neutral with regard to jurisdictional claims in published maps and institutional affiliations.

Copyright: (C) 2022 by the authors. Licensee MDPI, Basel, Switzerland. This article is an open access article distributed under the terms and conditions of the Creative Commons Attribution (CC BY) license (https:// creativecommons.org/licenses/by/ $4.0 /)$.
1 Department of Civil Engineering, School of Engineering, King Mongkut's Institute of Technology Ladkrabang, Bangkok 10520, Thailand

2 Synterra Co., Ltd., Bangkok 10310, Thailand; nakib305@gmail.com

3 Soil Engineering Research Center, Department of Civil Engineering, King Mongkut's University of Technology North Bangkok, Bangkok 10800, Thailand; pitthaya.j@eng.kmutnb.ac.th

4 School of Ceramic Engineering, Institute of Engineering, Suranaree University of Technology, Nakhon Ratchasima 30000, Thailand; jiratchaya@sut.ac.th

* Correspondence: salisa.ch@kmitl.ac.th; Tel.: +66-81-598-9969

\begin{abstract}
This is the first study on "ribbed smoked sheets (RSS)" as a geogrid reinforcement in geotechnical engineering. An RSS is a kind of natural para rubber. RSS (grade 3) was designed as a biaxial geogrid with an aperture size of $20 \mathrm{~mm} \times 20 \mathrm{~mm}$ and a spacing of $20 \mathrm{~mm}$. The RSS was found to be a significant functional layer when applied to the subbase lateritic soil layer. The lateritic soil with an RSS reinforcing layer was greatly improved regarding the California bearing ratio (CBR). Numerical simulation using two-dimensional finite element software was used to determine the optimal number and positions of the RSS reinforcing layers in road embankment stabilization. The simulation data in terms of horizontal displacement of unreinforced road embankments was validated by the collected data from the actual construction site. The RSS reinforced layer was varied from one to three layers under 61 analysis conditions. The highest safety factor was obtained with two layers of RSS at $0.1 \mathrm{H}$ below the top of the road embankment and $0.4 \mathrm{H}$ below the first RSS layer, suggesting a suitable installation of the RSS reinforcing layer. The RSS is thus strongly recommended as a reinforcing material in low CBR lateritic soil for the road embankment.
\end{abstract}

Keywords: geosynthetics; geogrid; RSS; para rubber sheet; ribbed smoked sheet; road reinforcement

\section{Introduction}

A road embankment, which is the soil layer, can withstand strong compression but the tension property is very weak. The reinforcement material, which is stiffer than the road material, has become one alternative to apply for increasing stability, bearing capacity, and strength of soil, especially in road construction [1,2]. Geogrid, which is made from polymer materials, such as polypropylene, polyester, high-density polyethylene, or other polymers with high elastic properties, have been widely applied and placed in road embankments to improve the performance of weak subgrades and the base course for both paved and unpaved roads [3]. The biaxial geogrid is generally used for road reinforcement to distribute a load in two directions, which are the machine direction (MD) and cross direction (CD). The geogrid produces interlocking between aggregates and the geogrid [4], which creates an aggregate-geogrid composite [5] to form a confined zone with three functions (lateral restraint, bearing capacity increment, and membrane support). With the presence of the interlocking mechanisms, the geogrid can improve the lateral restraint at the interface and prevent both lateral and vertical movements. The higher shear strength surface is developed by using geogrid reinforcement to increase the bearing capacity and support the wheel load as a membrane support [4,6]. The biaxial geogrid can be applied to reduce the base course thickness by 30\% [7]. The thickness of a road embankment for both paved and unpaved surfaces can be reduced by $20 \%$ to $70 \%$ depending on the strength of the subgrade and the type of geogrid [8]. Therefore, geogrid reinforcement can increase the bearing capacity, reduce rutting, and decrease the settlement [9]. 
The performance of geogrid reinforcement depends on the reinforcing layer and the reinforcing position. The position of the geogrid reinforcement depends on various parameters, which play an important role, such as the distance of the topmost layer from the loading bed $(\mathrm{u})$, the distance between geogrid layers $(\mathrm{h})$, the loading area width (B), the width of the geogrid layers $(b)$, the number of geogrid layers $(N)$, the loading distance from the edge of slope (D), and the slope angle $(\beta)$. The bearing capacity increases with an increase in the reinforcing layers within the road embankment [10]. In some cases, geogrid reinforcement with a single layer is sufficient if the depth of the reinforcing position is appropriate [11]. El Sawwaf [12] found that the optimal amount of the reinforcing position for $\mathrm{u} / \mathrm{b}$ and $\mathrm{h} / \mathrm{b}$ were 0.6 and 0.5 , respectively. Alamshahi and Hataf [13] proposed that having two layers of a geogrid-reinforced slope is the optimal number of geogrid reinforcements based on the bearing capacity. Esmaeili et al. [14] investigated the optimal position for geogrid reinforcement, which led to the best performance of the geogrid reinforcement by considering the maximum bearing capacity of the railway embankment; the optimized results were the normalized distances $\mathrm{u} / \mathrm{B}=0.3$ and $\mathrm{h} / \mathrm{B}=0.4$ with three layers of the geogrid reinforcement, based on $B, u$, and h being $4.8 \mathrm{~m}, 1.44 \mathrm{~m}$, and $1.92 \mathrm{~m}$, respectively. Moreover, four layers of the geogrid reinforcement did not increase the bearing capacity of the railway embankment.

In recent years, biodegradable- or natural-reinforced materials have been investigated to increase their applications in geotechnical engineering $[15,16]$. Currently, para rubber prices are experiencing a problem in Thailand. Moreover, the natural para rubber is interesting not only because of its superior properties but also to overcome the problem of supply and price in Thailand. Natural rubber is a biopolymer consisting of isoprene units $\left(\mathrm{C}_{5} \mathrm{H}_{8}\right)_{\mathrm{n}}$ linked together in a 1,4 cis-configuration. Not only poly cis-isoprene molecules but also other cellular components are included in the natural rubber, while synthetic rubber is almost completely composed of polyisoprene with not more than $90 \%$ of cis-bond. Because of its molecular structure with a high cis-bond content of over $99.5 \%$ and high molecular weight, the natural rubber has superior resilience, elasticity, abrasion resistance, efficient heat dispersion, and impact resistance to synthetic rubber [17-19]. Para rubber can be used to produce latex, block rubber, RSS, etc. Para rubber was researched by many researchers in the forms of para rubber floor tiles [20], admixture in concrete blocks [21], para soil-cement road [22], etc. Concentrated latex was suggested to mix with soil cement because it can improve the properties of soil-cement roads, such as an increase in compression, strength, and bending strength, while reducing absorption and dust [23]. However, research on using RSS reinforcement for its geogrid function has yet to be published.

Therefore, preliminary research was conducted on the application of RSS as a reinforced material to improve the strength of lateritic soil. Moreover, this research aimed to investigate the optimal layer and position of RSS reinforcement on the road embankment, which was located on soft ground areas based on safety analysis conducted using numerical simulation.

\section{Properties of RSS}

RSS is made from coagulated latex sheets, which are smoked in an oven at a suitable temperature. According to the green book standard by the Rubber Authority of Thailand [24], RSS is classified into six quality grades, which are RSS grades $1 \mathrm{X}, 1,2,3,4$, and 5. The best quality is RSS grade 1X, with strict quality control regarding the purity, elasticity, colors, air bubbles, defections, shape, and moisture. On the other hand, the worst quality is RSS grade 5 [24].

In this research, RSS grade 3 was designed as a biaxial geogrid in the shape of a square with an aperture size of $20 \mathrm{~mm} \times 20 \mathrm{~mm}$ and a spacing of $20 \mathrm{~mm}$, as shown in Figure 1 . The apertures can interlock with surrounding aggregates, forming a confined zone and allowing for the draining of water [6]. The aperture size was designed based on the research of Koerner [6] and Han et al. [25], which suggested that the size of a geogrid aperture should be between $10 \mathrm{~mm}$ and $100 \mathrm{~mm}$, with an open area percentage between $40 \%$ and 
$90 \%$. Due to the efficiency of interlocking, the ratio of aperture size (A) to particle diameter size (D) of a biaxial geogrid, namely, A/D, should be between 1.30-1.71 [25].

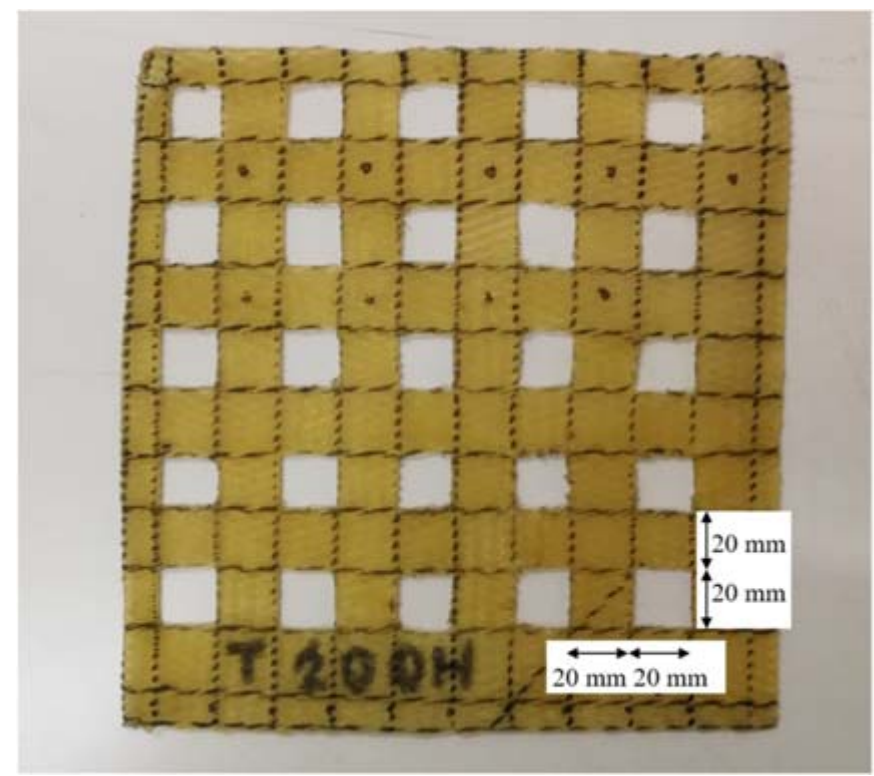

Figure 1. Apertures size of RSS for road reinforcement.

According to ASTM D5199-12 [26], the thickness of the RSS was approximately $2.90 \mathrm{~mm}$ to $3.90 \mathrm{~mm}$ for a single sheet and approximately $7.20 \mathrm{~mm}$ to $7.60 \mathrm{~mm}$ for a double sheet. The ultimate tensile strength of RSS was measured using the wide-width strip method [27]. A universal testing machine (Instron 5567) at a speed of $10 \mathrm{~mm} / \mathrm{min}$ (10\% of strain rate) with a gauge length of $100 \mathrm{~mm}$ was used for the testing. The load was applied to the RSS until failure. As a result, the ultimate tensile strength of the RSS was $0.64 \mathrm{kN} / \mathrm{m}$ and $1.313 \mathrm{kN} / \mathrm{m}$ for a single sheet and a double sheet, respectively. The ultimate tensile strength of the RSS was within the typical range of geogrid [28].

\section{Preliminary Study of RSS as Reinforcing Materials}

The performance of RSS with a geogrid function was evaluated in the laboratory by measuring the strength of the lateritic soil based on the California Bearing Ratio (CBR) test. According to the DH-S 205/2532 standard [29] from the Thailand Department of Highways, the classification of this grade of lateritic soil is appropriate for application as a subbase material based on the grain size distribution shown in Table 1. Lateritic soil is classified into five grades: A, B, C, D, and E. The first order grade is A, with the best lateritic soil properties with the highest maximum dry density and CBR values but the lowest optimal water content value. Meanwhile, the last order grade is E with lateritic soil with the lowest maximum dry density and CBR but the highest optimal water content [30].

To determine the performance of RSS reinforcement on the CBR of lateritic soil, the lateritic soil grade E was used in this research. Moreover, the lateritic soil grade E was classified into two gradations to understand the RSS performance based on differences in subsoil strength. For lateritic soil grade E with a high CBR (CBR $=64.53 \%$ ), which was called E1, the percent passing through sieve nos. 10, 40, and 200 of the lateritic soil was $70.00 w t \%, 31.00 w t \%$, and $6.00 w t \%$, respectively. For lateritic soil grade E with low $\mathrm{CBR}(\mathrm{CBR}=40.56 \%)$, which was called E2, the percent passing through sieve nos. 10,40 , and 200 of the lateritic soil was $75.67 \mathrm{wt} \%, 37.10 \mathrm{wt} \%$, and $13.51 \mathrm{wt} \%$, respectively. Gradation of lateritic soil was performed via sieve analysis in order to determine the grain size distribution, as shown in Table 1 and Figure 2. 
Table 1. Grain size distributions for lateritic soil.

\begin{tabular}{|c|c|c|c|c|c|c|c|}
\hline \multirow{3}{*}{ Sieve Size } & \multicolumn{7}{|c|}{ Percent Passing by Weight (\%) } \\
\hline & \multicolumn{5}{|c|}{ Standard of DH-S 205/2532 } & \multicolumn{2}{|c|}{ In This Research } \\
\hline & Grade A & Grade B & Grade C & Grade D & Grade E & Grade E1 & Grade E2 \\
\hline $2^{\prime \prime}(50.00 \mathrm{~mm})$ & 100 & 100 & - & - & - & - & - \\
\hline $1^{\prime \prime}(25.00 \mathrm{~mm})$ & - & - & 100 & 100 & 100 & 100 & 100 \\
\hline $3 / 8^{\prime \prime}(9.50 \mathrm{~mm})$ & $30-65$ & $40-75$ & $50-85$ & $60-100$ & - & - & - \\
\hline No. $10(2.00 \mathrm{~mm})$ & $15-40$ & $20-45$ & $25-50$ & $40-70$ & $40-100$ & 70 & 75.67 \\
\hline No. $40(0.425 \mathrm{~mm})$ & $8-20$ & $15-30$ & $15-30$ & $25-45$ & $20-50$ & 31 & 37.10 \\
\hline No. $200(0.075 \mathrm{~mm})$ & $2-8$ & $5-20$ & $5-15$ & $5-20$ & $6-20$ & 6 & 13.51 \\
\hline
\end{tabular}

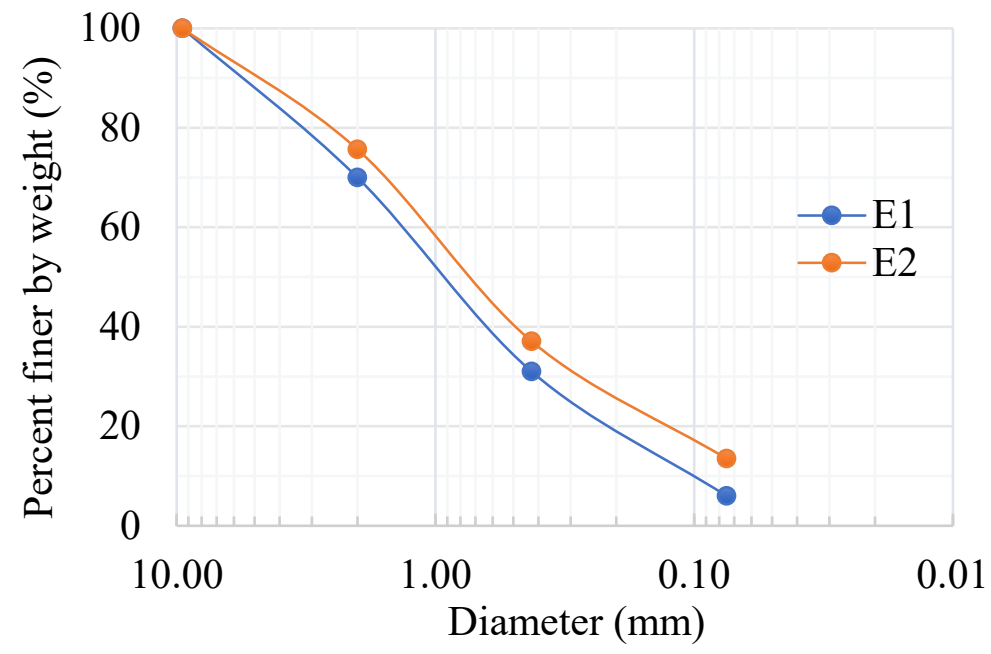

Figure 2. Grain sizes distribution of E1 and E2.

The liquid limit (LL), plastic limit (PL), and plasticity index (PI) of the lateritic soil were characterized using Atterberg's limits test based on the AASHTO T 89 [31] and AASHTO T 90 [32] standards. The LL and PL of E1 were $48.00 \%$ and $21.54 \%$, respectively. The PI, which was LL-PL, of E1 was $26.46 \%$. Moreover, The LL and PL of E2 were $48.00 \%$ and $23.23 \%$, respectively. The PI of E2 was $24.77 \%$. The average optimum moisture content (OMC) of lateritic soil was found to be $14 \%$ at a maximum dry density of $1.86 \mathrm{~g} / \mathrm{cm}^{3}$.

\section{CBR Testing}

CBR testing was carried out and compared under four testing conditions, which were lateritic soil E1 non-reinforcement (E1), lateritic soil E2 non-reinforcement (E2), lateritic soil E1 with RSS reinforcement (E1-RSS), and lateritic soil E2 with RSS reinforcement (E2-RSS), respectively.

The standard for the CBR testing method, namely, ASTM D1883 [33], was tested based on the condition of OMC at maximum dry density, which was obtained from conducting the modified compaction test [34]. The maximum dry density of E1 and E2 was $1.86 \mathrm{~g} / \mathrm{cm}^{3}$ at the OMC of $14.00 \%$. A CBR under non-reinforcement conditions (E1 and E2) with lateritic soils E1 and E2 were mixed with tap water until reaching homogeneity. The soil samples were transferred into CBR molds (cylindrical molds with a $152.4 \mathrm{~mm}$ inner diameter and a height of $177.8 \mathrm{~mm}$ ) in sequential order with five equal-sized soil sample amounts reaching up to the top edge of the mold. Each layer of soil sample was compacted with 56 blows using a $10.00 \mathrm{lbf}(44.48 \mathrm{~N})$ rammer, which was dropped from a $457.2 \mathrm{~mm}$ height. After compaction, the perforated base plate and spacer disk were taken out. The molds containing compacted soil samples were weighed and recorded. A disk of coarse filter paper was placed on the top of the soil sample prior to overturning the CBR mold. In penetration testing, a steel penetration piston with a $50 \mathrm{~mm}$ diameter proving ring 
was inserted at the center point for penetration. Load measurements corresponding to deformation at every $0.64 \mathrm{~mm}(0.025 \mathrm{in})$ were taken to calculate the bearing capacity of the lateritic soils E1 and E2.

A CBR test under reinforcement conditions (E1-RSS and E2-RSS) followed the same preparation procedure with non-reinforcement conditions (E1 and E2). On the other hand, the RSS with an aperture size of $20 \mathrm{~mm} \times 20 \mathrm{~mm}$ was cut as a circular shape and placed between layers 2 and 3 of the soil samples in the CBR mold, as shown in Figure 3.

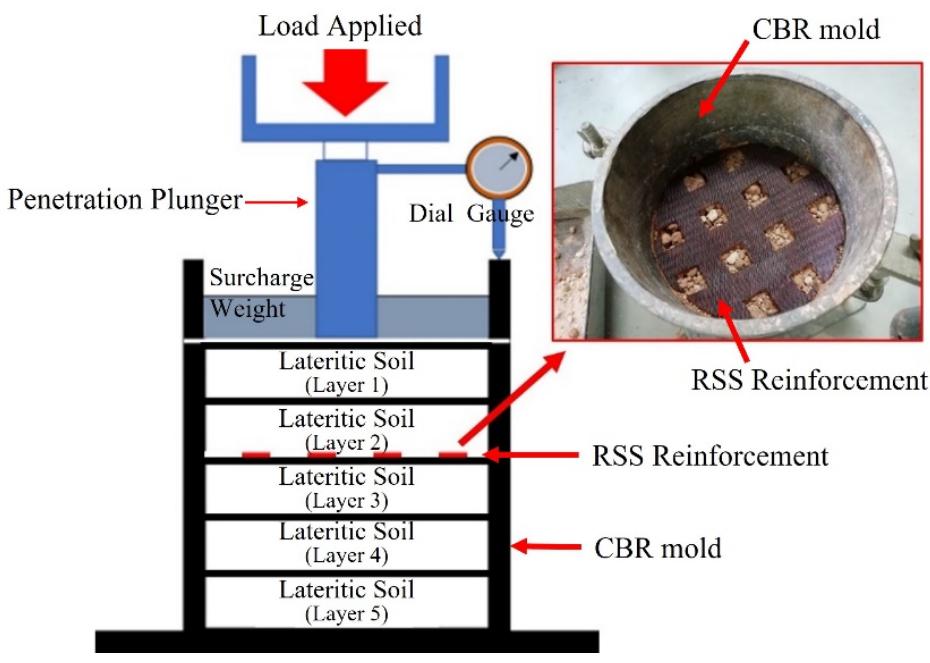

Figure 3. The position of RSS in the CBR mold.

To determine the effect of RSS reinforcement on the CBR of lateritic soil, E1 (CBR $=64.53 \%$ ) and $\mathrm{E} 2(\mathrm{CBR}=40.56 \%)$ were representative of lateritic soil in the cases of high CBR and low CBR, respectively. By considering the effect of RSS-reinforced lateritic soil with a high CBR value, E1 and E1-RSS were compared as shown in Table 2. The CBR value in the case of E1-RSS (CBR $=64.31 \%)$ was lower than the case of E1 $(\mathrm{CBR}=64.53 \%)$. This result showed that in cases with RSS reinforcement, the CBR of the lateritic soil was decreased by $0.34 \%$. Meanwhile, E2 and E2-RSS were compared to determine the effect of RSS-reinforced lateritic soil on a low CBR value. The CBR value in the case of E2-RSS (CBR $=49.95 \%)$ was higher than the $\mathrm{E} 2$ case ( $\mathrm{CBR}=40.56 \%$ ), with a percentage difference of $23.15 \%$ as presented in Table 2 . Therefore, the RSS was strongly recommended to improve the strength of lateritic soil, which had low CBR values. In the case of RSS reinforcement for soil with high CBR values, it is not recommended as a reinforcing material because it acts as a weak layer in hard soil according to the results of geogrid reinforcement, which are more efficient for low-CBR soil [6,35-37].

Table 2. The comparison of CBR values in RSS reinforcement.

\begin{tabular}{ccccc}
\hline \multirow{2}{*}{ Soil Types } & \multicolumn{2}{c}{ Testing Conditions } & CBR (\%) & $\begin{array}{c}\text { Percentage } \\
\text { Difference (\%) }\end{array}$ \\
\hline \multirow{2}{*}{ High CBR } & Non-reinforced & (E1) & 64.53 & -0.34 (Decreased) \\
& Reinforced 1 layer & (E1-RSS) & 64.31 & \\
\hline \multirow{2}{*}{ Low CBR } & Non-reinforced & (E2) & 40.56 & +23.15 (Increased) \\
& Reinforced 1 layer & (E2-RSS) & 49.95 & \\
\hline
\end{tabular}

\section{Numerical Simulation}

The finite element method (FEM) was chosen to confirm the number of effective layers and the position of the RSS-reinforced road embankment. PLAXIS (American Bentley Systems, Inc., Exton, PA, USA) ennsylvania is the most reliable software for FEM modeling and solving problems in geotechnical work using two-dimensional (2D) FEM under plane 
strain conditions $[38,39]$. Moreover, several previous works revealed that the simulation results from PLAXIS software are aligned with the actual situation in complex ground conditions [40-42]. PLAXIS software is therefore suitable for simulating the geometry of the road embankment. The typical geometry of canal-side roads and subsoils were modeled as the condition of an unreinforced road embankment. A nominal surcharge of $10 \mathrm{kN} / \mathrm{m}$ was assigned for traffic-load modeling. The condition of a very fine mesh was generated in the FEM model. The construction stage feature allowed for incremental backfill placement, which was divided into three layers. The RSS reinforcement was placed on the top of a compacted backfill soil layer-by-layer until reaching the full height of the road embankment at $2 \mathrm{~m}$. The water level was assigned at $1.5 \mathrm{~m}$ below the ground surface. The in-situ stresses in the subsoil layer were generated using the $\mathrm{K}_{\mathrm{o}}$ procedure. The compacted backfill soil as an additional layer was assigned as a material parameter according to the stress state induced after an incremental backfill layer. During the construction stage, undrained analysis was applied to simulate the construction of the road embankment. After completion of the full height of the road embankment, drainage analysis was applied to simulate the consolidation process for the road embankment. Moreover, the subsoil model was created and the results from the FEM software were validated based on horizontal displacement profiles, which were measured in the real construction site at the Ayutthaya rural road no. 5034 (AY.5034).

\subsection{Validation Site}

AY.5034 is a canal-side road, located on soft Bangkok clay in the Don Thong subdistrict, Sena district, Phra Nakhon Si Ayutthaya, Thailand. AY.5034 has asphaltic concrete with a two-lane road (section of $6 \mathrm{~m}$ wide and a $1 \mathrm{~m}$ wide shoulder on each side), consisting of one lane in one direction and one lane in the other. The side slope of the canal-side road is $1 \mathrm{~V}: 1.5 \mathrm{H}$. The depth of the canal is about $4 \mathrm{~m}$ below the ground surface and the height of the road embankment is about $2 \mathrm{~m}$ high from the ground surface. The water level in the canal of the existing road was at a $1.5 \mathrm{~m}$ depth below the ground surface. The general soil profile and soil properties were investigated at KM. $6+200$, as shown in Figure 4 . The topsoil was about $1.5 \mathrm{~m}$ in depth. The uppermost $15 \mathrm{~m}$ in depth in the subsoil could be divided into six layers. The first layer was the $1.5 \mathrm{~m}$ thick medium clay, which was a dark grey color. The second was the very soft to soft clay layer down to $7.5 \mathrm{~m}$ in depth. The third layer was a stiff clay layer with a medium-light grey color at 7.5 to $9.0 \mathrm{~m}$ in depth. The fourth layer was stiff sandy clay ranging from 9.0 to $10.5 \mathrm{~m}$ in depth. The very dense silty yellowish-gray sand down to $12.0 \mathrm{~m}$ in depth formed the fifth layer and the medium dense to dense yellowish-gray silty sand ranging from 12.0 to $15.0 \mathrm{~m}$ in depth formed the sixth layer. Underlying the hard clay was sand and hard sandy clay, which extended to $19 \mathrm{~m}$ in depth.
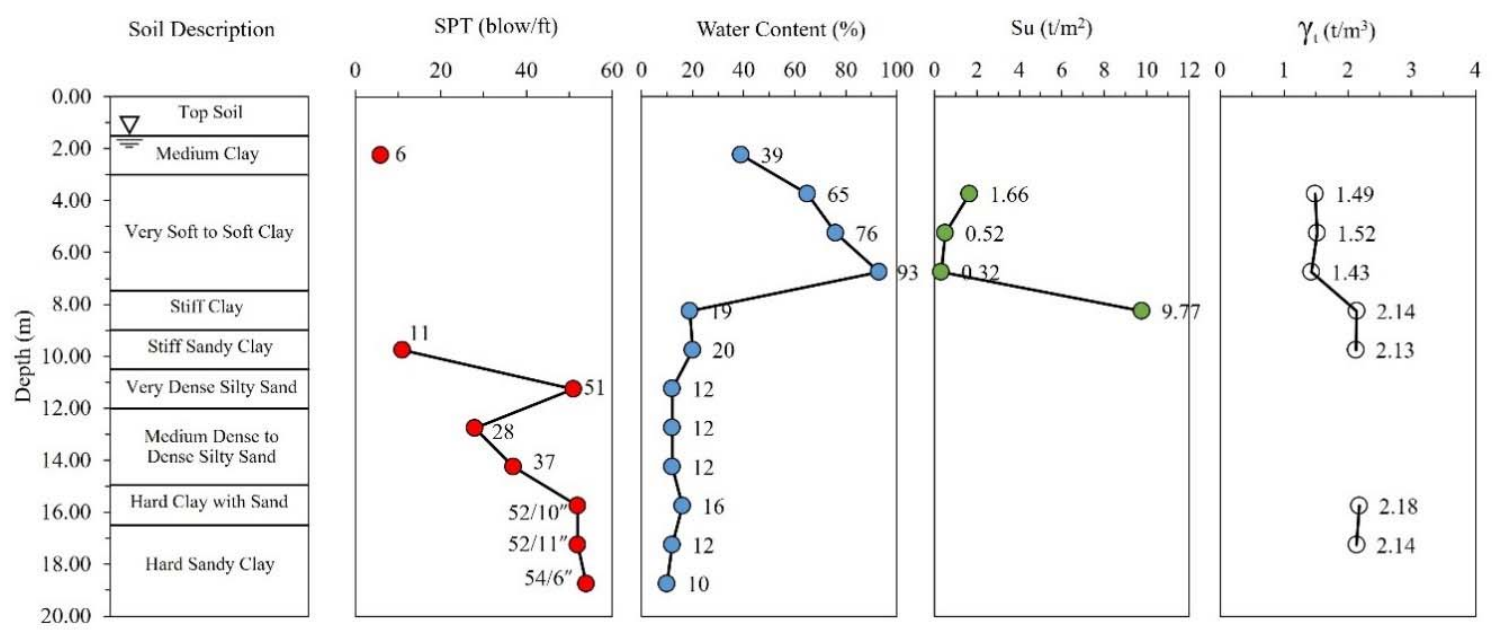

Figure 4. Soil profile and soil properties at AY.5034. 


\subsection{Model Geometry and Materials Properties}

\subsubsection{Geometry of Road Embankment}

The geometry of the road embankment was presented using a cross-section of AY.5034, which was constructed along the Khong-Khun Si (irrigation canal). This kind of geometry was suitable for simulating using a 2D under-plane strain condition with a 15-node element. To avoid any boundary effects, the FEM model was created with a $330 \mathrm{~m}$ width in the $x$-axis (from $x_{\min }$ of $-175 \mathrm{~m}$ to $x_{\max }$ of $155 \mathrm{~m}$ ) and $64 \mathrm{~m}$ in depth in the $y$-axis (from $y_{\min }$ of $-60 \mathrm{~m}$ to $y_{\max }$ of $4 \mathrm{~m}$ ), which is enough boundary size [43].

The road embankment and the canal were modeled with a $2 \mathrm{~m}$ height and $4 \mathrm{~m}$ depth from the ground surface. The water level in the canal was assigned at $1.5 \mathrm{~m}$ below the ground surface. The subsoil layer model was divided into 11 layers based on the soil profile of AY.5034, as shown in Figure 5. The roller and fixed boundaries were set to the side and the bottom of the model boundaries, respectively.

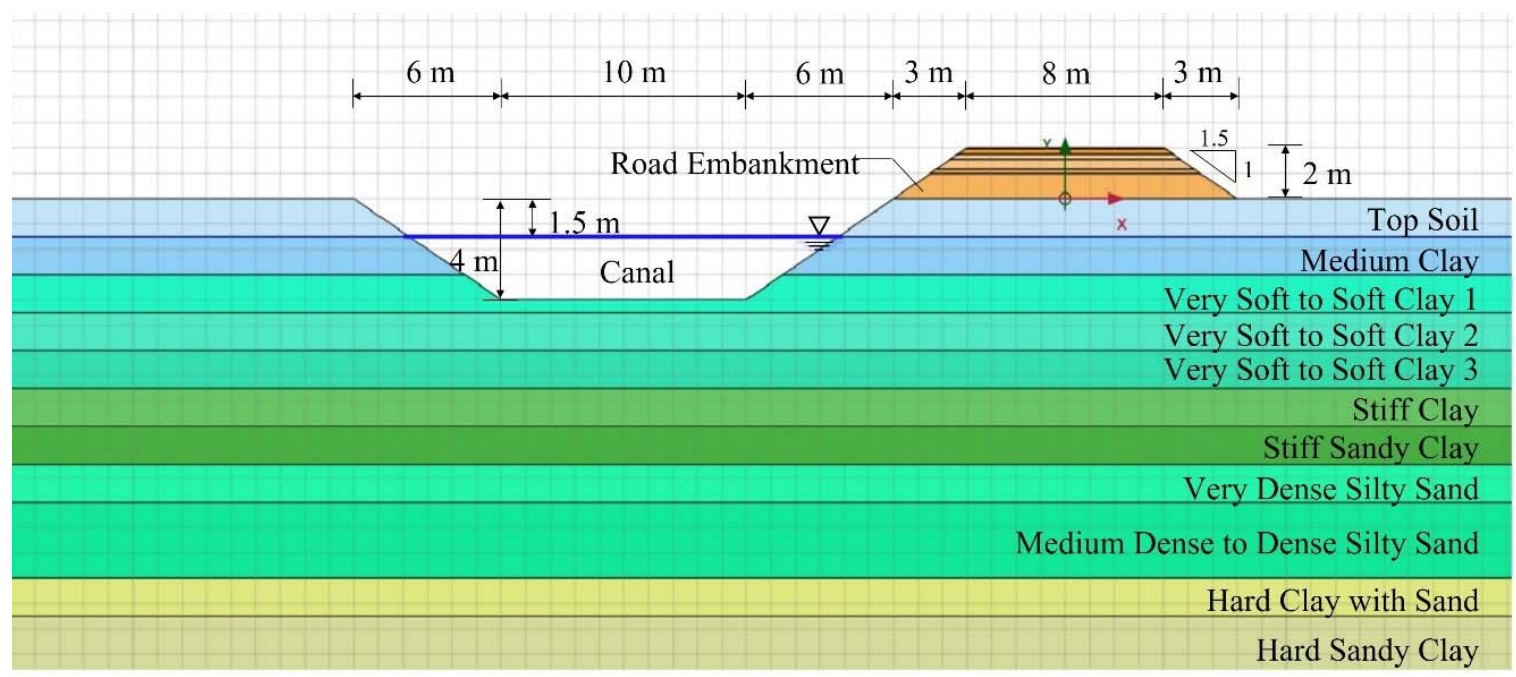

Figure 5. FEM model.

\subsubsection{Subsoil and Road Embankment Properties in FEM Model}

The model parameter was assigned based on the soil profile of AY.5034 (Figure 4). The soft soil model (SSM) under undrained conditions was assigned to the uppermost $7.5 \mathrm{~m}$ in depth with an overconsolidation ratio $(\mathrm{OCR})=1.2$, which included the topsoil, medium clay, and soft clay layers. The strength parameters of the topsoil were cohesion $c^{\prime}=14 \mathrm{kPa}$ and friction angle $\varnothing^{\prime}=25^{\circ}$. Additional values for analysis were as follows: modified compression index $\lambda^{*}=0.17$ and modified swelling index $\kappa^{*}=0.020$. The medium clay $\left(1.5 \mathrm{~m}\right.$ to $3.0 \mathrm{~m}$ in depth) with $c^{\prime}=15 \mathrm{kPa}, \varnothing^{\prime}=25^{\circ}, \lambda^{*}=0.12$, and $\kappa^{*}=0.020$ [44].

The soft soil layer ( $3.0 \mathrm{~m}$ to $7.5 \mathrm{~m}$ in depth) could be divided into three sublayers, namely, very soft to soft clay 1 (3.0 $\mathrm{m}$ to $4.5 \mathrm{~m}$ in depth), very soft to soft clay 2 ( $4.5 \mathrm{~m}$ to $6.0 \mathrm{~m}$ in depth) and very soft to soft clay $3(6.0 \mathrm{~m}$ to $7.5 \mathrm{~m}$ in depth). The strength parameters were determined based on the testing data at AY.5304 by using strength parameters $c^{\prime}$ between 10 and $14 \mathrm{kPa}$ and $\varnothing^{\prime}=25^{\circ}$. The additional values for analysis were as follows: $\lambda^{*}=0.10$ for very soft to soft clay 1 and 0.03 for very soft to soft clay 2 and 3 , and $\kappa^{*}=0.009$ for the soft soil layer [44].

The elastic perfectly plastic Mohr-Coulomb model (MCM) was assigned for the model of underlying stiff clay to hard sandy clay, which was located from $7.5 \mathrm{~m}$ to $19 \mathrm{~m}$ in depth. The stiff clay was located between $7.5 \mathrm{~m}$ and $9.0 \mathrm{~m}$ in depth. The strength parameters with the undrained condition were obtained from the validation site with $c^{\prime}=95 \mathrm{kPa}$, the Poisson's ratio $v^{\prime}=0.25$, and elasticity $E^{\prime}=19,000 \mathrm{kPa}$. The strength parameters with the undrained condition of stiff sandy clay layer $\left(9.0 \mathrm{~m}\right.$ to $10.5 \mathrm{~m}$ depths) were $c^{\prime}=105 \mathrm{kPa}$, $\varnothing^{\prime}=10^{\circ}, v^{\prime}=0.25$, and $E^{\prime}=21,000 \mathrm{kPa}$. The very dense silty sand $(10.5 \mathrm{~m}$ to $12.0 \mathrm{~m}$ depths) and medium dense to dense silty sand (12.0 $\mathrm{m}$ to $15.0 \mathrm{~m}$ in depth) with the drained 
condition were assigned to the FEM model with constant values for $c^{\prime}=5 \mathrm{kPa}, v^{\prime}=0.30$, and $E^{\prime}=53,000 \mathrm{kPa}$, while the value of $\varnothing^{\prime}=40^{\circ}$ and $35^{\circ}$ for very dense silty sand and medium dense to dense silty sand, respectively.

The FEM input parameters of hard clay with sand (15.0 $\mathrm{m}$ to $16.5 \mathrm{~m}$ in depth) in the analysis were as follows: $c^{\prime}=150 \mathrm{kPa}, \varnothing^{\prime}=10^{\circ}, E^{\prime}=30,000 \mathrm{kPa}$, and $v^{\prime}=0.25$. Hard sandy clay was the final layer that was located from $15 \mathrm{~m}$ to $60 \mathrm{~m}$ in depth. The model parameters used for the FEM analysis were as follows: $E^{\prime}=54,000 \mathrm{kPa}, v^{\prime}=0.25, c^{\prime}=270 \mathrm{kPa}$, and $\varnothing^{\prime}=10^{\circ}$. The modulus of elasticity and strength parameters for the subsoil layers, which were generated as a foundation, are presented in Table 3.

Moreover, the material properties of the road embankment for the FEM analysis were established from a previous study by Wulandari and Tjandra [45], which analyzed a geotextile reinforced road embankment using PLAXIS 2D. The MCM with drained behavior was used for the model of a road embankment. The strength parameters were $c^{\prime}=1 \mathrm{kPa}$, $\varnothing^{\prime}=33^{\circ}$, and the dilatancy angle $\psi=3^{\circ}$. The additional material parameters for FEM analyzes were $E^{\prime}=50,000 \mathrm{kPa}$ and $v^{\prime}=0.3$. The interface coefficient $R_{\text {in }}=0.8$ [46]. The material properties of the road embankment model for the FEM simulations are tabulated in Table 3.

\subsubsection{RSS Properties in FEM Model}

The RSS was modeled as a geogrid element in the FEM software. An axial stiffness $(E A)$, which is the elastic modulus of the reinforcement material $(E)$ and the cross-sectional area per unit width in the perpendicular plane $(A)$, is the required input value for the geogrid element. The $E A$ was calculated from the ultimate tensile strength of RSS, which was obtained using the wide-width strip method [27]. The double-sheet of RSS, which was $7.6 \mathrm{~mm}$ in thickness, was applied as the thickness of the reinforcement material in the FEM model. The ultimate tensile strength $\left(T_{\text {ult }}\right)$ was $1.313 \mathrm{kN} / \mathrm{m}$, which is typical of the peak tensile strength range [28]. Therefore, $E A$ was $3.46 \mathrm{kN} / \mathrm{m}$ at a strain of $25 \%$. The properties of the RSS used in this analysis are tabulated in Table 4. 
Table 3. The material properties used in the FEM analysis of the road embankment with RSS reinforcement.

\begin{tabular}{|c|c|c|c|c|c|c|c|c|c|c|c|c|}
\hline Materials & Depth (m) & Model & Behaviors & $\gamma_{\text {sat }}\left(\mathrm{kN} / \mathrm{m}^{3}\right)$ & $\gamma_{u n}\left(\mathrm{kN} / \mathrm{m}^{3}\right)$ & $E^{\prime}$ ref $(\mathrm{kPa})$ & $v^{\prime}$ & $u *$ & $\kappa^{*}$ & $c^{\prime}(\mathbf{k P a})$ & $\varnothing^{\prime}\left({ }^{\circ}\right)$ & OCR \\
\hline \multicolumn{13}{|l|}{ Subsoil } \\
\hline Top soil & $0-1.5$ & SSM & Undrained & 15.0 & 13.0 & & & 0.17 & 0.020 & 14 & 25 & 1.2 \\
\hline Medium clay & $1.5-3.0$ & SSM & Undrained & 16.5 & 14.5 & & & 0.12 & 0.020 & 15 & 25 & 1.2 \\
\hline Very soft to soft clay 1 & $3.0-4.5$ & SSM & Undrained & 15.0 & 13.0 & & & 0.10 & 0.009 & 14 & 25 & 1.2 \\
\hline Very soft to soft clay 2 & $4.5-6.0$ & SSM & Undrained & 15.0 & 13.0 & & & 0.03 & 0.009 & 10 & 25 & 1.2 \\
\hline Very soft to soft clay 3 & $6.0-7.5$ & SSM & Undrained & 15.0 & 13.0 & & & 0.03 & 0.009 & 10 & 25 & 1.2 \\
\hline Stiff clay & $7.5-9.0$ & MCM & Undrained & 21.0 & 19.0 & 19,000 & 0.25 & & & 95 & & \\
\hline Stiff sandy clay & $9.0-10.5$ & MCM & Undrained & 21.0 & 19.0 & 21,000 & 0.25 & & & 105 & 10 & \\
\hline Very dense silty sand & $10.5-12.0$ & MCM & Drained & 22.0 & 20.0 & 53,000 & 0.30 & & & 5 & 40 & \\
\hline $\begin{array}{l}\text { Medium dense to } \\
\text { dense silty sand }\end{array}$ & $12.0-15.0$ & $\mathrm{MCM}$ & Drained & 22.0 & 20.0 & 53,000 & 0.30 & & & 5 & 35 & \\
\hline Hard clay with sand & $15.0-16.5$ & $\mathrm{MCM}$ & Undrained & 21.0 & 19.0 & 30,000 & 0.25 & & & 150 & 10 & \\
\hline Hard sandy clay & $16.5-19.0$ & $\mathrm{MCM}$ & Undrained & 22.0 & 20.0 & 54,000 & 0.25 & & & 270 & 10 & \\
\hline \multicolumn{13}{|l|}{ Road Embankment [45] } \\
\hline Materials & Model & Behaviors & $\gamma_{\text {sat }}\left(\mathrm{kN} / \mathrm{m}^{3}\right)$ & $\gamma_{u n}\left(\mathrm{kN} / \mathrm{m}^{3}\right)$ & $E^{\prime}$ ref $(\mathbf{k P a})$ & $v^{\prime}$ & $\psi\left({ }^{\circ}\right)$ & $R_{\text {in }}$ & & & & \\
\hline Fill material & MCM & Drained & 18.0 & 18.00 & 50,000 & 0.3 & 3.00 & 0.8 & & & & \\
\hline
\end{tabular}

Table 4. The properties of the RSS in the double sheet condition.

\begin{tabular}{|c|c|c|c|c|c|}
\hline Material & Mesh Type & Apertures Size (mm) & Thickness (mm) & Ultimate Tensile Strength, $T_{\text {ult }}(\mathrm{kN} / \mathrm{m})$ & Axial Stiffness, $E A(\mathrm{kN} / \mathrm{m})$ \\
\hline RSS-geogrid & Rectangular apertures & $20 \times 20$ & 7.591 & 1.313 & 3.460 \\
\hline
\end{tabular}




\section{Variable Assignment in FEM Model}

To study the optimal layer and position of the RSS reinforcement on a road embankment considering the factor of safety, the parameters of the reinforced road embankment were applied through parametric analysis. The FEM model considered the following parameters: distance from the topmost reinforcing layer to the road embankment surface $(\mathrm{u})$, spacing between the reinforcing layers $(\mathrm{h})$, height of the road embankment above the subsoil level (h), width of the road embankment (B), and the number of reinforcing layers $(\mathrm{N})$, as shown in Figure 6.

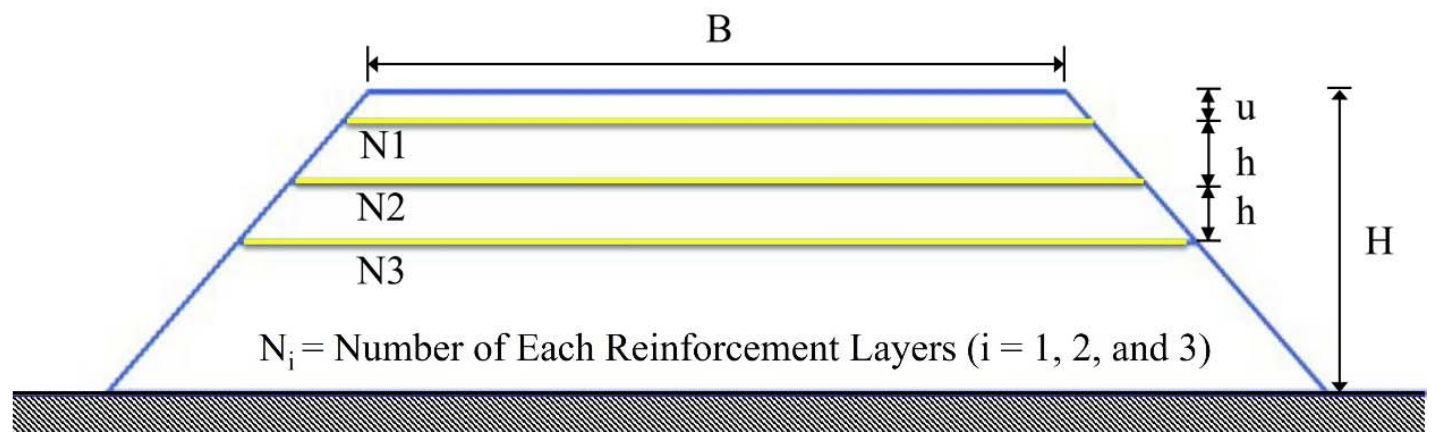

Figure 6. The parameters of road embankment reinforced with RSS geogrid layers.

\subsection{The Concept of Reinforcement Conditions}

The concept of $\mathrm{u} / \mathrm{H}$ and $\mathrm{h}(\mathrm{N}-1) / \mathrm{H}$ were utilized to analyze optimal reinforcing layers and reinforcing positions for the road embankment reinforced using the RSS. This concept depended on the following parameters: $\mathrm{u}, \mathrm{h}, \mathrm{H}$, and $\mathrm{N}$ of a reinforced road embankment. The general equation has been approved, as shown in Equation (1):

$$
\mathrm{u}+(\mathrm{N}-1)(\mathrm{h}) \leq \mathrm{H}
$$

For one layer of RSS reinforcement $(\mathrm{N}=1)$ :

$$
\mathrm{u}+(0)(\mathrm{h}) \leq \mathrm{H}
$$

$\mathrm{u}_{\min }=0 \mathrm{H}, \mathrm{u}_{\max }=1 \mathrm{H}:$

$$
\therefore \mathrm{u} / \mathrm{H} \leq 1
$$

For two layers of RSS reinforcement $(\mathrm{N}=2)$ :

$$
\mathrm{u}+(1)(\mathrm{h}) \leq \mathrm{H}
$$

$\mathrm{u}_{\min }=0 \mathrm{H}, \mathrm{u}_{\max }=0.5 \mathrm{H} ;(1) \mathrm{h}_{\min }=0 \mathrm{H},(1) \mathrm{h}_{\max }=0.5 \mathrm{H}$.

For three layers of RSS reinforcement $(\mathrm{N}=3)$ :

$$
\mathrm{u}+(2)(\mathrm{h}) \leq \mathrm{H}
$$

$\mathrm{u}_{\min }=0 \mathrm{H}, \mathrm{u}_{\max }=0.5 \mathrm{H} ;(2) \mathrm{h}_{\min }=0 \mathrm{H},(2) \mathrm{h}_{\max }=0.5 \mathrm{H}:$

$$
\begin{gathered}
\therefore \mathrm{N}=2 \text {, and } \mathrm{N}=3 ; \mathrm{u} / \mathrm{H} \leq 0.5 \\
\mathrm{~h}(\mathrm{~N}-1) / \mathrm{H} \leq 0.5
\end{gathered}
$$

Therefore, from the concept of $\mathrm{u} / \mathrm{H}$ and $\mathrm{h}(\mathrm{N}-1) / \mathrm{H}$, it was concluded that $\mathrm{u} / \mathrm{H} \leq 1$ (Equation (3)) should be applied for $\mathrm{N}=1$, while $\mathrm{u} / \mathrm{H} \leq 0.5$ (Equation (6)) and $\mathrm{h}(\mathrm{N}-1) /$ $\mathrm{H} \leq 0.5$ (Equation (7)) should be applied for $\mathrm{N}=2$ and 3 .

The limitations of the $\mathrm{u} / \mathrm{H}$ and $\mathrm{h}(\mathrm{N}-1) / \mathrm{H}$ concepts are as follows: 
(1) A surcharge load acts on the full width of a road embankment (for this study, a surcharge load $=10 \mathrm{kN} / \mathrm{m}$ );

(2) $\mathrm{H}$ is constant (for this study, $\mathrm{H}=2.00 \mathrm{~m}$ height);

(3) $\mathrm{u}, \mathrm{h}$, and $\mathrm{N}$ are different in different positions;

(4) The effect of a side slope is ignored.

\subsection{Analysis Conditions}

The 2D FEM analysis was carried out to evaluate and confirm the efficiency of the RSSreinforced road embankment and determine the reinforcing layers and reinforcing positions, comparing between the unreinforced $(\mathrm{N}=0)$ and reinforced $(\mathrm{N}=1,2,3)$ conditions with 61 analysis conditions, as shown in Table 5 .

Table 5. The 61 analysis conditions.

\begin{tabular}{|c|c|c|c|c|c|c|c|c|}
\hline \multirow{3}{*}{$\begin{array}{l}\text { No. of RSS } \\
\text { Layers, N }\end{array}$} & \multirow{3}{*}{ Conditions } & \multicolumn{7}{|c|}{ Reinforcing Positions } \\
\hline & & \multicolumn{2}{|c|}{ Spacing } & \multicolumn{2}{|c|}{ From the Road Surface } & \multicolumn{3}{|c|}{ From the Ground Surface (m) } \\
\hline & & $\mathbf{h}(\mathbf{N}-\mathbf{1})$ & $\mathrm{h}(\mathrm{m})$ & $\mathbf{u}$ & $\mathbf{u}(\mathrm{m})$ & N1 & N2 & N3 \\
\hline $\mathrm{N}=0$ & N0 & - & - & - & - & - & - & - \\
\hline \multirow{10}{*}{$\mathrm{N}=1$} & $\mathrm{~N} 1-\mathrm{u}_{1}$ & - & - & $0.1 \mathrm{H}$ & 0.20 & 1.80 & - & - \\
\hline & $\mathrm{N} 1-\mathrm{u}_{2}$ & - & - & $0.2 \mathrm{H}$ & 0.40 & 1.60 & - & - \\
\hline & $\mathrm{N} 1-\mathrm{u}_{3}$ & - & - & $0.3 \mathrm{H}$ & 0.60 & 1.40 & - & - \\
\hline & $\mathrm{N} 1-\mathrm{u}_{4}$ & - & - & $0.4 \mathrm{H}$ & 0.80 & 1.20 & - & - \\
\hline & $\mathrm{N} 1-\mathrm{u}_{5}$ & - & - & $0.5 \mathrm{H}$ & 1.00 & 1.00 & - & - \\
\hline & $\mathrm{N} 1-\mathrm{u}_{6}$ & - & - & $0.6 \mathrm{H}$ & 1.20 & 0.80 & - & - \\
\hline & $\mathrm{N} 1-\mathrm{u}_{7}$ & - & - & $0.7 \mathrm{H}$ & 1.40 & 0.60 & - & - \\
\hline & $\mathrm{N} 1-\mathrm{u}_{8}$ & - & - & $0.8 \mathrm{H}$ & 1.60 & 0.40 & - & - \\
\hline & N1-u & - & - & $0.9 \mathrm{H}$ & 1.80 & 0.20 & - & - \\
\hline & $\mathrm{N} 1-\mathrm{u}_{10}$ & - & - & $1.0 \mathrm{H}$ & 2.00 & 0.00 & - & - \\
\hline \multirow{25}{*}{$\mathrm{N}=2$} & $\mathrm{~N} 2-\mathrm{h}_{1} \mathrm{u}_{1}$ & & & $0.1 \mathrm{H}$ & 0.20 & 1.80 & 1.60 & - \\
\hline & $\mathrm{N} 2-\mathrm{h}_{1} \mathrm{u}_{2}$ & & & $0.2 \mathrm{H}$ & 0.40 & 1.60 & 1.40 & - \\
\hline & $\mathrm{N} 2-\mathrm{h}_{1} \mathrm{u}_{3}$ & $0.1 \mathrm{H}$ & 0.20 & $0.3 \mathrm{H}$ & 0.60 & 1.40 & 1.20 & - \\
\hline & $\mathrm{N} 2-\mathrm{h}_{1} \mathrm{u}_{4}$ & & & $0.4 \mathrm{H}$ & 0.80 & 1.20 & 1.00 & - \\
\hline & $\mathrm{N} 2-\mathrm{h}_{1} \mathrm{u}_{5}$ & & & $0.5 \mathrm{H}$ & 1.00 & 1.00 & 0.80 & - \\
\hline & $\mathrm{N} 2-\mathrm{h}_{2} \mathrm{u}_{1}$ & & & $0.1 \mathrm{H}$ & 0.20 & 1.80 & 1.40 & - \\
\hline & $\mathrm{N} 2-\mathrm{h}_{2} \mathrm{u}_{2}$ & & & $0.2 \mathrm{H}$ & 0.40 & 1.60 & 1.20 & - \\
\hline & $\mathrm{N} 2-\mathrm{h}_{2} \mathrm{u}_{3}$ & $0.2 \mathrm{H}$ & 0.40 & $0.3 \mathrm{H}$ & 0.60 & 1.40 & 1.00 & - \\
\hline & $\mathrm{N} 2-\mathrm{h}_{2} \mathrm{u}_{4}$ & & & $0.4 \mathrm{H}$ & 0.80 & 1.20 & 0.80 & - \\
\hline & $\mathrm{N} 2-\mathrm{h}_{2} \mathrm{u}_{5}$ & & & $0.5 \mathrm{H}$ & 1.00 & 1.00 & 0.60 & - \\
\hline & $\mathrm{N} 2-\mathrm{h}_{3} \mathrm{u}_{1}$ & & & $0.1 \mathrm{H}$ & 0.20 & 1.80 & 1.20 & - \\
\hline & $\mathrm{N} 2-\mathrm{h}_{3} \mathrm{u}_{2}$ & & & $0.2 \mathrm{H}$ & 0.40 & 1.60 & 1.00 & - \\
\hline & $\mathrm{N} 2-\mathrm{h}_{3} \mathrm{u}_{3}$ & $0.3 \mathrm{H}$ & 0.60 & $0.3 \mathrm{H}$ & 0.60 & 1.40 & 0.80 & - \\
\hline & $\mathrm{N} 2-\mathrm{h}_{3} \mathrm{u}_{4}$ & & & $0.4 \mathrm{H}$ & 0.80 & 1.20 & 0.60 & - \\
\hline & $\mathrm{N} 2-\mathrm{h}_{3} \mathrm{u}_{5}$ & & & $0.5 \mathrm{H}$ & 1.00 & 1.00 & 0.40 & - \\
\hline & $\mathrm{N} 2-\mathrm{h}_{4} \mathrm{u}_{1}$ & & & $0.1 \mathrm{H}$ & 0.20 & 1.80 & 1.00 & - \\
\hline & $\mathrm{N} 2-\mathrm{h}_{4} \mathrm{u}_{2}$ & & & $0.2 \mathrm{H}$ & 0.40 & 1.60 & 0.80 & - \\
\hline & $\mathrm{N} 2-\mathrm{h}_{4} \mathrm{u}_{3}$ & $0.4 \mathrm{H}$ & 0.80 & $0.3 \mathrm{H}$ & 0.60 & 1.40 & 0.60 & - \\
\hline & $\mathrm{N} 2-\mathrm{h}_{4} \mathrm{u}_{4}$ & & & $0.4 \mathrm{H}$ & 0.80 & 1.20 & 0.40 & - \\
\hline & $\mathrm{N} 2-\mathrm{h}_{4} \mathrm{u}_{5}$ & & & $0.5 \mathrm{H}$ & 1.00 & 1.00 & 0.20 & - \\
\hline & $\mathrm{N} 2-\mathrm{h}_{5} \mathrm{u}_{1}$ & & & $0.1 \mathrm{H}$ & 0.20 & 1.80 & 0.80 & - \\
\hline & $\mathrm{N} 2-\mathrm{h}_{5} \mathrm{u}_{2}$ & & & $0.2 \mathrm{H}$ & 0.40 & 1.60 & 0.60 & - \\
\hline & $\mathrm{N} 2-\mathrm{h}_{5} \mathrm{u}_{3}$ & $0.5 \mathrm{H}$ & 1.00 & $0.3 \mathrm{H}$ & 0.60 & 1.40 & 0.40 & - \\
\hline & $\mathrm{N} 2-\mathrm{h}_{5} \mathrm{u}_{4}$ & & & $0.4 \mathrm{H}$ & 0.80 & 1.20 & 0.20 & - \\
\hline & $\mathrm{N} 2-\mathrm{h}_{5} \mathrm{u}_{5}$ & & & $0.5 \mathrm{H}$ & 1.00 & 1.00 & 0.00 & - \\
\hline
\end{tabular}


Table 5. Cont.

\begin{tabular}{|c|c|c|c|c|c|c|c|c|}
\hline \multirow{3}{*}{$\begin{array}{l}\text { No. of RSS } \\
\text { Layers, N }\end{array}$} & \multirow{3}{*}{ Conditions } & \multicolumn{7}{|c|}{ Reinforcing Positions } \\
\hline & & \multicolumn{2}{|c|}{ Spacing } & \multicolumn{2}{|c|}{ From the Road Surface } & \multicolumn{3}{|c|}{ From the Ground Surface (m) } \\
\hline & & $\mathbf{h}(\mathbf{N}-\mathbf{1})$ & $\mathrm{h}(\mathrm{m})$ & $\mathbf{u}$ & $\mathrm{u}(\mathrm{m})$ & N1 & N2 & N3 \\
\hline \multirow{25}{*}{$\mathrm{N}=3$} & $\mathrm{~N} 3-\mathrm{h}_{1} \mathrm{u}_{1}$ & & & $0.1 \mathrm{H}$ & 0.20 & 1.80 & 1.70 & 1.60 \\
\hline & $\mathrm{N} 3-\mathrm{h}_{1} \mathrm{u}_{2}$ & & & $0.2 \mathrm{H}$ & 0.40 & 1.60 & 1.50 & 1.40 \\
\hline & $\mathrm{N} 3-\mathrm{h}_{1} \mathrm{u}_{3}$ & $0.1 \mathrm{H}$ & 0.10 & $0.3 \mathrm{H}$ & 0.60 & 1.40 & 1.30 & 1.20 \\
\hline & $\mathrm{N} 3-\mathrm{h}_{1} \mathrm{u}_{4}$ & & & $0.4 \mathrm{H}$ & 0.80 & 1.20 & 1.10 & 1.00 \\
\hline & $\mathrm{N} 3-\mathrm{h}_{1} \mathrm{u}_{5}$ & & & $0.5 \mathrm{H}$ & 1.00 & 1.00 & 0.90 & 0.80 \\
\hline & $\mathrm{N} 3-\mathrm{h}_{2} \mathrm{u}_{1}$ & & & $0.1 \mathrm{H}$ & 0.20 & 1.80 & 1.60 & 1.40 \\
\hline & $\mathrm{N} 3-\mathrm{h}_{2} \mathrm{u}_{2}$ & & & $0.2 \mathrm{H}$ & 0.40 & 1.60 & 1.40 & 1.20 \\
\hline & $\mathrm{N} 3-\mathrm{h}_{2} \mathrm{u}_{3}$ & $0.2 \mathrm{H}$ & 0.20 & $0.3 \mathrm{H}$ & 0.60 & 1.40 & 1.20 & 1.00 \\
\hline & $\mathrm{N} 3-\mathrm{h}_{2} \mathrm{u}_{4}$ & & & $0.4 \mathrm{H}$ & 0.80 & 1.20 & 1.00 & 0.80 \\
\hline & $\mathrm{N} 3-\mathrm{h}_{2} \mathrm{u}_{5}$ & & & $0.5 \mathrm{H}$ & 1.00 & 1.00 & 0.80 & 0.60 \\
\hline & $\mathrm{N} 3-\mathrm{h}_{3} \mathrm{u}_{1}$ & & & $0.1 \mathrm{H}$ & 0.20 & 1.80 & 1.50 & 1.20 \\
\hline & $\mathrm{N} 3-\mathrm{h}_{3} \mathrm{u}_{2}$ & & & $0.2 \mathrm{H}$ & 0.40 & 1.60 & 1.30 & 1.00 \\
\hline & $\mathrm{N} 3-\mathrm{h}_{3} \mathrm{u}_{3}$ & $0.3 \mathrm{H}$ & 0.30 & $0.3 \mathrm{H}$ & 0.60 & 1.40 & 1.10 & 0.80 \\
\hline & N3-h $3 \mathrm{u}_{4}$ & & & $0.4 \mathrm{H}$ & 0.80 & 1.20 & 0.90 & 0.60 \\
\hline & $\mathrm{N} 3-\mathrm{h}_{3} \mathrm{u}_{5}$ & & & $0.5 \mathrm{H}$ & 1.00 & 1.00 & 0.70 & 0.40 \\
\hline & $\mathrm{N} 3-\mathrm{h}_{4} \mathrm{u}_{1}$ & & & $0.1 \mathrm{H}$ & 0.20 & 1.80 & 1.40 & 1.00 \\
\hline & $\mathrm{N} 3-\mathrm{h}_{4} \mathrm{u}_{2}$ & & & $0.2 \mathrm{H}$ & 0.40 & 1.60 & 1.20 & 0.80 \\
\hline & $\mathrm{N} 3-\mathrm{h}_{4} \mathrm{u}_{3}$ & $0.4 \mathrm{H}$ & 0.40 & $0.3 \mathrm{H}$ & 0.60 & 1.40 & 1.00 & 0.60 \\
\hline & $\mathrm{N} 3-\mathrm{h}_{4} \mathrm{u}_{4}$ & & & $0.4 \mathrm{H}$ & 0.80 & 1.20 & 0.80 & 0.40 \\
\hline & $\mathrm{N} 3-\mathrm{h}_{4} \mathrm{u}_{5}$ & & & $0.5 \mathrm{H}$ & 1.00 & 1.00 & 0.60 & 0.20 \\
\hline & $\mathrm{N} 3-\mathrm{h}_{5} \mathrm{u}_{1}$ & & & $0.1 \mathrm{H}$ & 0.20 & 1.80 & 1.30 & 0.80 \\
\hline & $\mathrm{N} 3-\mathrm{h}_{5} \mathrm{u}_{2}$ & & & $0.2 \mathrm{H}$ & 0.40 & 1.60 & 1.10 & 0.60 \\
\hline & $\mathrm{N} 3-\mathrm{h}_{5} \mathrm{u}_{3}$ & $0.5 \mathrm{H}$ & 0.50 & $0.3 \mathrm{H}$ & 0.60 & 1.40 & 0.90 & 0.40 \\
\hline & $\mathrm{N} 3-\mathrm{h}_{5} \mathrm{u}_{4}$ & & & $0.4 \mathrm{H}$ & 0.80 & 1.20 & 0.70 & 0.20 \\
\hline & $\mathrm{N} 3-\mathrm{h}_{5} \mathrm{u}_{5}$ & & & $0.5 \mathrm{H}$ & 1.00 & 1.00 & 0.50 & 0.00 \\
\hline
\end{tabular}

\subsection{Factor of Safety Analysis}

The factor of safety (FS) was used to analyze and confirm the optimal layer and position of RSS reinforcement on the road embankment. The results of the FS, which was analyzed using the PLAXIS program, were calculated based on the phi-c reduction method [47]. The phi-c reduction method was calculated by reducing the soil strength parameters $(\tan \varnothing$ and c) until the failure of the road embankment or subsoil layer occurs. The total multiplier $\left(\Sigma M_{\mathrm{sf}}\right)$ was used to define the value of the soil-strength parameters at a given stage in the FEM analysis, as in Equation (8):

$$
\Sigma M_{\mathrm{sf}}=\frac{\tan \phi_{\text {input }}}{\tan \phi_{\text {reduced }}}=\frac{C_{\text {input }}}{C_{\text {reduced }}}
$$

where the soil strength parameters with the subscript "input" refer to the properties entered in the material sets, while the soil strength parameters with the subscript "reduced" refer to the reduced values used in the FEM analysis. $\Sigma M_{\mathrm{sf}}$ was set to 1.0 at the start of a calculation step to set all material strengths to their unreduced values. The soil strength parameters were successively reduced automatically until failure occurred. The FS is given by Equation (9):

$$
\mathrm{FS}=\frac{\text { Available strength }}{\text { Strength at failure }}=\text { Value of } \Sigma M_{\mathrm{sf}} \text { at failure }
$$




\section{Analysis of Results}

\subsection{Model Validation}

The subsoil model was validated by using horizontal displacement profiles $\left(u_{\mathrm{x}}\right)$, which were measured at a real construction site at AY.5034 (KM. $5+400)$. The inclinometer was installed on 6 June 2018 to measure the $u_{\mathrm{x}}$ at a $16 \mathrm{~m}$ depth below the ground's surface. For model validation, the $u_{\mathrm{x}}$ of the subsoil layer at 462 days (11 September 2020) after installation from the AY.5034 was measured and compared with the $u_{\mathrm{x}}$ from the FEM model under the following analysis conditions: (1) the road embankment model with a nominal surcharge of $10 \mathrm{kN} / \mathrm{m}$ were assigned at 462 days and (2) the $u_{\mathrm{x}}$ from the FEM model was considered at the coordinates of $(-5,0)$ to $(-5,-16)$ at the same position as the inclinometer at AY.5034.

The validation graph shows the relationship between the $u_{\mathrm{x}}$ in the $x$-axis and the subsoil depth in the $y$-axis. The maximum $u_{\mathrm{x}}$ occurred at the ground's surface, which was $34.39 \mathrm{~mm}$ with a rate of $2.99 \mathrm{~mm} / \mathrm{month}$. For the uppermost $5 \mathrm{~m}$ depth below the ground's surface, $u_{\mathrm{x}}$ clearly occurred and it continuously reduced with an increase in the depth of subsoil. On the other hand, the $u_{\mathrm{x}}$ slightly occurred underlying a depth of $5 \mathrm{~m}$ below the ground surface, which went down from $5 \mathrm{~m}$ to $11 \mathrm{~m}$ depths. At depths more than $11 \mathrm{~m}$ below the ground's surface, $u_{\mathrm{x}}$ did not occur at AY.5034. Moreover, the results of $u_{\mathrm{x}}$ from the FEM analysis followed a similar trend while measuring $u_{\mathrm{x}}$ at AY.5034. This result could be used to confirm that the input parameter on the FEM model was reliable, as shown in Figure 7.

Horizontal Displacement, $u_{\mathrm{x}}(\mathrm{mm})$

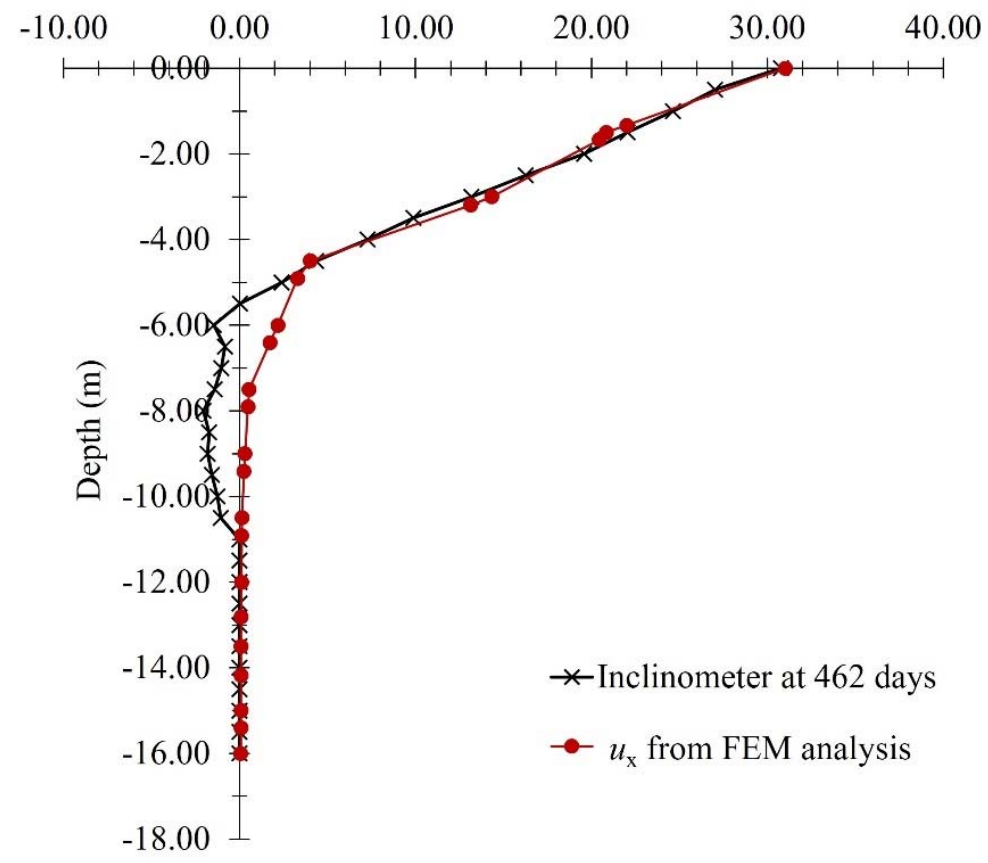

Figure 7. The validation data.

\subsection{Optimal Layer and Position of RSS Reinforced Road Embankment}

Comparing the FS of the unreinforced road embankment $(\mathrm{N}=0)$ and reinforced road embankment with one layer of RSS $(\mathrm{N}=1)$, the FS of $\mathrm{N}=0$ was 1.255. The FS of $\mathrm{N}=1$ continuously reduced with an increase in $\mathrm{u} / \mathrm{H}$. The FS of the reinforced road embankment was higher than that of the unreinforced road embankment. This means that the RSS was appropriate to install in the structure of the road embankment as the reinforcement material. In addition, the $\mathrm{FS}$ of $\mathrm{N}=1$ at $\mathrm{u} / \mathrm{H}=0.1$, which was called $\mathrm{N} 1-\mathrm{u}_{1}$, had a maximum $\mathrm{FS}$ at 1.415, as shown in Figure 8. 


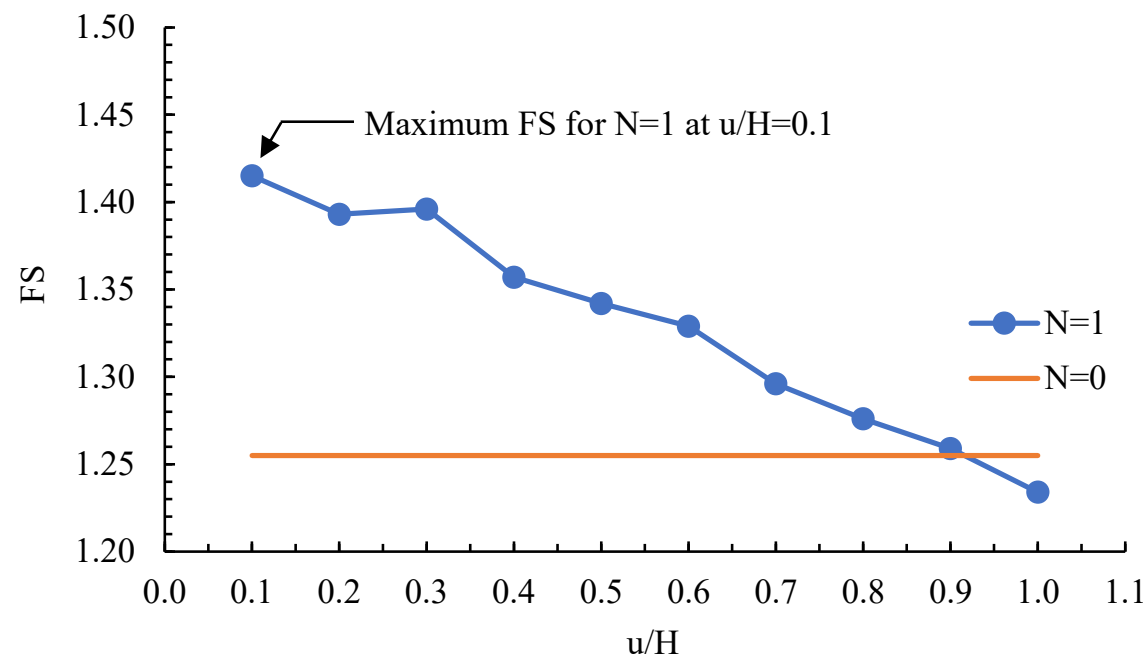

Figure 8. The FS results in the conditions of $\mathrm{N}=0$ and $\mathrm{N}=1$.

Figure 9 presents the relationship between FS and $\mathrm{h}(\mathrm{N}-1) / \mathrm{H}$ of the reinforced road embankment with two layers of RSS $(\mathrm{N}=2)$ by varying $\mathrm{u} / \mathrm{H}$ from 0.1 to 0.5 . The FS increased with an increase of $\mathrm{u} / \mathrm{H}$, which had the highest $\mathrm{FS}$ at $\mathrm{u} / \mathrm{H}=0.1$ and the lowest $\mathrm{FS}$ at $\mathrm{u} / \mathrm{H}=0.1$. Reducing $\mathrm{h}(\mathrm{N}-1) / \mathrm{H}$ did not have much of an effect on the FS in the case of $\mathrm{u} / \mathrm{H}=0.2$ to 0.5 . On the other hand, the $\mathrm{FS}$ of $\mathrm{u} / \mathrm{H}=0.1$ showed a significant increase in the decrease of $h(\mathrm{~N}-1) / \mathrm{H}$. This result followed a similar trend to the results of the reinforced road embankment with three layers of RSS $(\mathrm{N}=3)$, as shown in Figure 10.

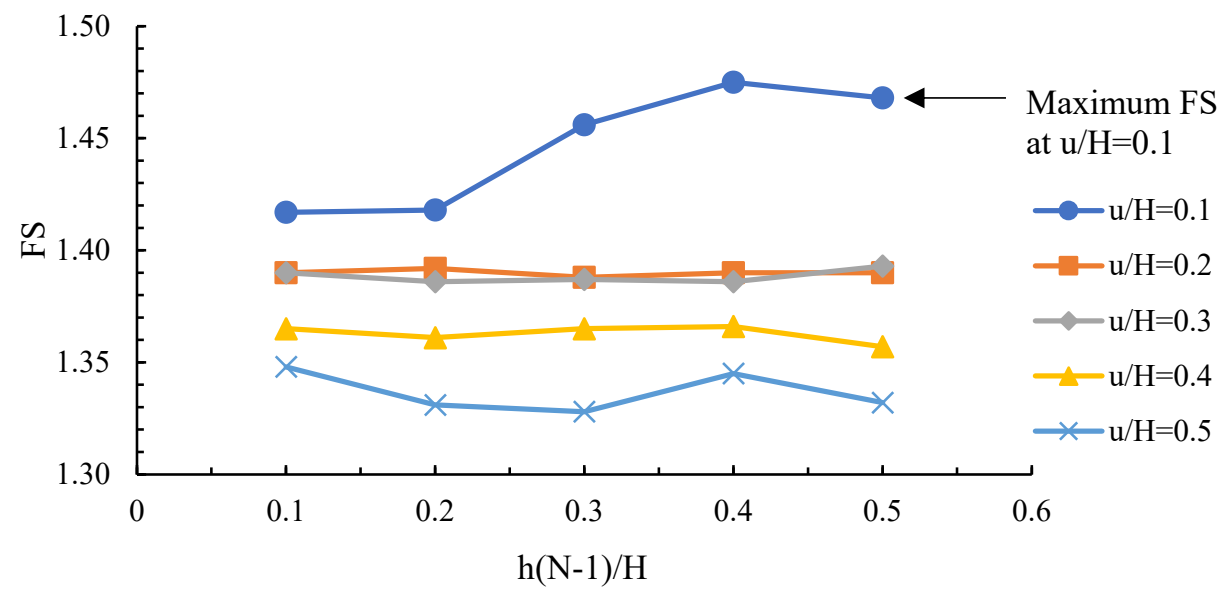

Figure 9. The FS results in the conditions with $\mathrm{N}=2$.

According to the results of FS in the case of $\mathrm{N}=1$ to $\mathrm{N}=3$, it confirmed that the optimal position of RSS reinforced road embankment in the top layer was $\mathrm{u} / \mathrm{H}=0.1$. The relationship between FS and $h(N-1) / H$ in the condition of $\mathrm{N}=2$ and $\mathrm{N}=3$ were plotted and compared to analyze the optimization of reinforcing layers, as shown in Figure 11. The FS in the condition of $\mathrm{N}=2$ was higher than the FS in the condition of $\mathrm{N}=3$ for all analyzed $\mathrm{h}(\mathrm{N}-1) / \mathrm{H}$ conditions.

Therefore, two layers of RSS-reinforced road embankment were optimal. This result is consistent with the suggestion of Alamshahi and Hataf [13], which mentioned that two layers of reinforcement material were suitable to increase the bearing capacity of the embankment. Moreover, Esmaeili et al. [14] mentioned that four layers of reinforcement material have no effect on increasing the bearing capacity. The FS of $\mathrm{h}(\mathrm{N}-1) / \mathrm{H}=0.4$ was 1.475 , which was the maximum FS. The results of the analysis were similar to the results from the geogrid stabilized high railway embankment from Esmaeili et al. [14]. Thus, the 
$\mathrm{N} 2-\mathrm{h}_{4} \mathrm{u}_{1}$ condition, which included two RSS layers with the first layer of RSS at $0.1 \mathrm{H}$ below the road surface and the second layer of RSS at $0.4 \mathrm{H}$ below the position of the RSS in the first layer, provided the optimal number of layers and their positions for the reinforced road embankment when using RSS.

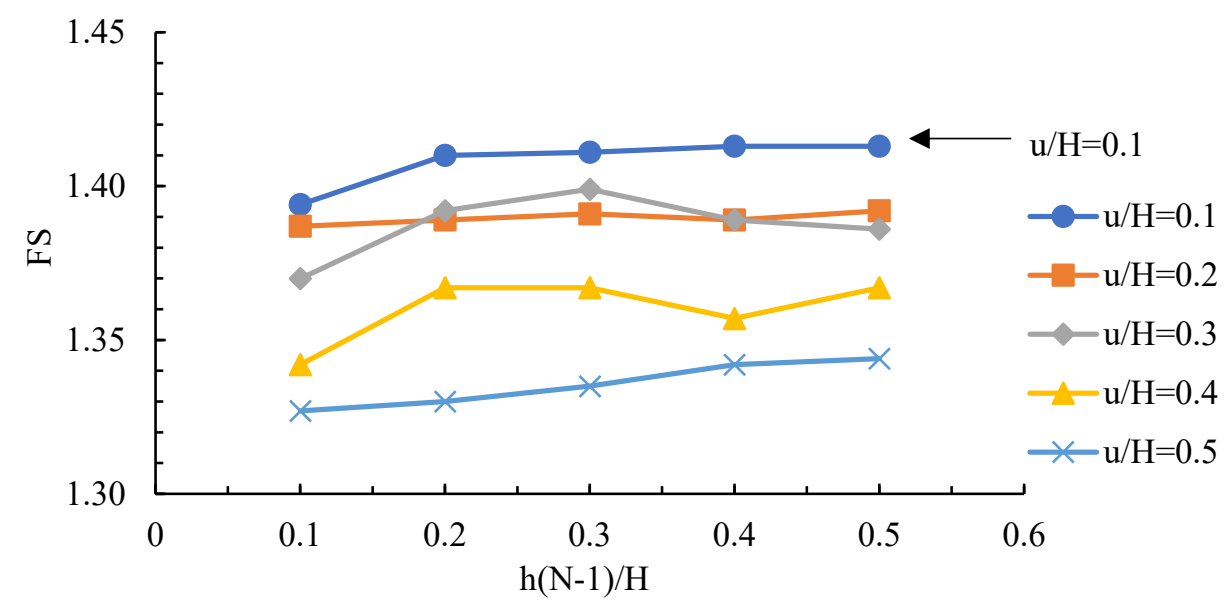

Figure 10. The FS results in the conditions with $\mathrm{N}=3$.

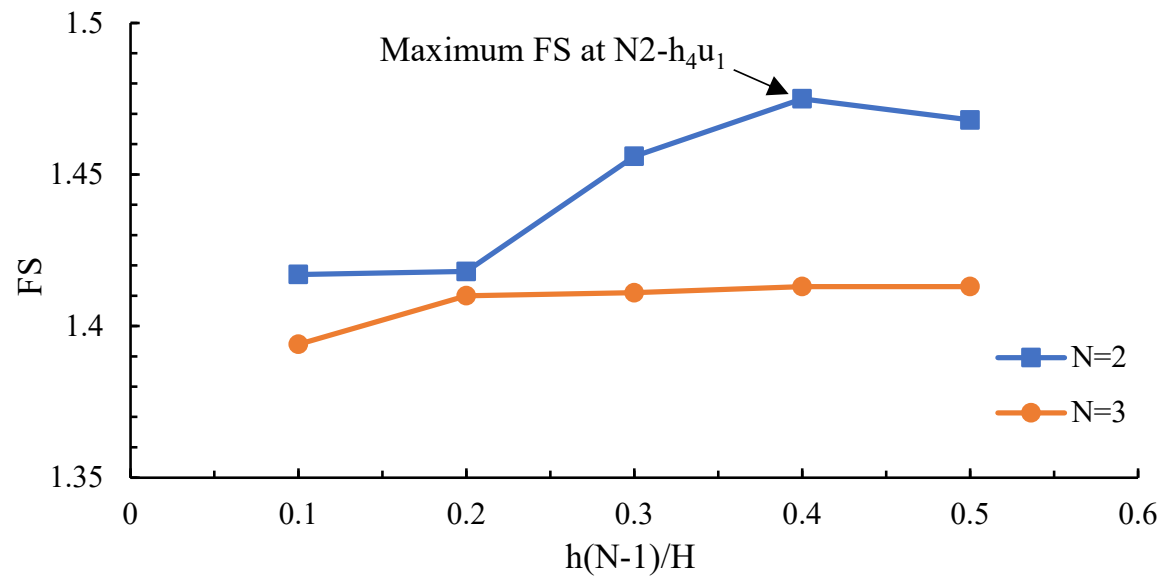

Figure 11. The relationship between FS and $h(\mathrm{~N}-1) / \mathrm{H}$ in the conditions with $\mathrm{u} / \mathrm{H}=0.1$.

\section{Conclusions}

Ribbed smoked sheet (RSS) was studied as a geogrid reinforcement in low CBR lateritic soil for a road embankment. The result from the laboratory test, together with the numerical simulation, confirmed the performance of the RSS reinforcing layer in the road embankments. The RSS functional layer could improve the CBR of the subbase lateritic soil layer. Using 2D FEM simulations, the RSS with two layers installed at $0.1 \mathrm{H}$ below the top of the road embankment and $0.4 \mathrm{H}$ below the first RSS layer demonstrated the highest safety factor value among all 61 analysis conditions. To be used as a reinforcement material in road embankments, the RSS is strongly recommended for low CBR soil stabilization. This is because the RSS can act as a weak layer in between the high-CBR soil layer of the road embankment.

Author Contributions: Conceptualization, S.C.; methodology, software, validation, and formal analysis, S.C. and N.A.; data curation and writing - original draft preparation, S.C.; writing-review and editing, S.C. and J.A.; visualization, supervision, and project administration, S.C.; funding acquisition, S.C. and P.J. All authors have read and agreed to the published version of the manuscript. 
Funding: This research was funded by Office of the Permanent Secretary, Ministry of Higher Education, Science, Research and Innovation under grant number RGNS 63-250, and the National Science, Research and Innovation Fund (NSRF) under Contract no. KMUTNB-FF-65-38.

Institutional Review Board Statement: Not applicable.

Informed Consent Statement: Not applicable.

Data Availability Statement: The data presented in this study are available on request from the corresponding author.

Acknowledgments: The authors would like to express their sincerest gratitude to the Department of Rural Roads in Thailand, King Mongkut's Institute of Technology Ladkrabang, Suranaree University of Technology (SUT), Thailand Science Research and Innovation (TSRI), and King Mongkut's University of Technology North Bangkok.

Conflicts of Interest: The authors declare no conflict of interest.

\section{References}

1. Tailor, R.M.; Shah, N.C. Applications of innovative materials for performance improvement of flexible pavement over expansive subgrade. Int. J. Geomate 2015, 8, 1197-1202. [CrossRef]

2. Shah, M.M.; Afzalur, R.M.; Islam, M.M.; Hossain, M.S. Effectiveness of jute geotextiles in flexible pavement construction. Int. J. Geomate 2016, 10, 1644-1648.

3. Anitha, J. Effect of geosynthetics on soft subgrade-literature review. Int. Res. J. Eng. Technol. 2017, 4, $1446-1448$.

4. Geogrids in Roadway and Pavement Systems. Available online: https://globalsynthetics.com.au/wp-content/uploads/2016/0 1/Global-Synthetics-Geogrids-in-Roadway-Pavement-Systems.pdf (accessed on 10 September 2021).

5. Moayed, R.Z.; Nazari, M. Effect of utilization of geosynthetic of reducing the required thickness of subbase layer of a two layered soil. World Acad. Sci. Eng. Tech. 2011, 49, 963-967.

6. $\quad$ Koerner, R.M. Designing with Geosynthetics, 6th ed.; Prentice Hall: Upper Saddle River, NJ, USA, 2012.

7. Ullagaddi, P.B.; Nagara, T.K. Investigation on geosynthetic reinforced two layered soil system. In Proceedings of the International Conferences on Case Histories in Geotechnical Engineering, Chicago, IL, USA, 2 May 2013.

8. Goud, N.; Umashankar, B. Planar reinforcements for flexible pavements. In Proceedings of the International Conference on Geotechniques for Infrastructure Project, Thiruvananthapuram, India, 27-28 February 2017.

9. Ziegler, M. Application of geogrid reinforced constructions: History, recent and future developments. Procedia Eng. 2017, 172, 42-51. [CrossRef]

10. Olaniyan, O.S.; Akolade, A.S. Reinforcement of subgrade soils with the use of geogrids. Int. J. Sci. Res. 2014, 3, 2579-2584. Available online: https:/ / www.ijsr.net/get_abstract.php?paper_id=2014772 (accessed on 12 October 2021).

11. Charles, A.A.; Yaw, A.T.; Samuel, K. Effects of soil properties and geogrid placement on CBR enhancement of lateritic soil for road pavement layers. Am. J. Civ. Eng. Archit. 2016, 4, 62-66. [CrossRef]

12. El Sawwaf, M. Behavior of strip footing on geogrid reinforced sand over a soft clay slope. Geotext. Geomembr. 2007, 25, 50-60. [CrossRef]

13. Alamshahi, S.; Hataf, N. Bearing capacity of strip footings on sand slopes reinforced with geogrid and grid anchors. Geotext. Geomembr. 2009, 27, 217-226. [CrossRef]

14. Esmaeili, M.; Naderi, B.; Neyestanaki, H.K.; Khodaverdian, A. Investigating the effect of geogrid on stabilization of high railway embankments. Soils Found. 2018, 58, 319-332. [CrossRef]

15. Artidteang, S.; Bergado, D.T.; Chaiyaput, S.; Tanchaisawat, T. Embankment reinforced with limited life geotextiles on soft clay. Proc. Inst. Civ. Eng. Ground Improv. 2015, 168, 130-143. [CrossRef]

16. Artidteang, S.; Tanchaisawat, T.; Bergado, D.T.; Chaiyaput, S. Natural fibers in reinforcement and erosion control applications with limited life geosynthetics. In Ground Improvement Case Histories: Compaction, Grouting and Geosynthetics; Elsevier: Amsterdam, The Netherlands, 2015; pp. 717-740. [CrossRef]

17. Ismail, H.; Ahmad, Z.; Mohd Ishak, Z.A. Comparison of cetyltrimethylammonium maleate and sulphenamide as an accelerator in carbon black filled natural rubber compounds. Polym. Test. 2001, 20, 607-614. [CrossRef]

18. Hayashi, Y. Production of natural rubber from Para rubber tree. Plant Biotechnol. J. 2009, 26, 67-70. [CrossRef]

19. Morton, M. Rubber Technology; Springer Science and Business Media: Boston, MA, USA, 2013.

20. Deepanya, V.; Suveero, K. Floor tiles made from the mixture of para rubber and plastic wastes from factories. J. Community Dev. Life Qual. 2018, 4, 451-460.

21. Khamput, P.; Suweero, K. Using of para-rubber to develop properties of concrete block mixed with ethylene vinyl acetate plastic in masonry. Int. J. Environ. Rural Dev. 2014, 5, 86-92.

22. Pinwiset, K.; Raksuntorn, W.; Witchayangkoon, B. An investigation and test of natural rubber latex soil cement road. Int. Trans. J. Eng. Manag. App. Sci. Technol. 2018, 9, 67-74. [CrossRef] 
23. Pahusuwanno, S.; Inkliang, K.; Hanhongart, B. A study of para soil cement road construction. In Proceedings of the 11th THAICID National Symposium, Nontaburi, Thailand, 20 June 2018. (In Thai).

24. Rubber Authority of Thailand. Available online: https://www.rubber.co.th/download/technical_data_of_rubber_61.pdf (accessed on 1 September 2021). (In Thai)

25. Han, B.; Ling, J.; Shu, X.; Gong, H.; Huang, B. Laboratory investigation of particle size effects on the shear behavior of aggregategeogrid interface. Constr. Build. Mater. 2017, 158, 1015-1025. [CrossRef]

26. ASTM D5199-12; Standard Test Method for Measuring the Nominal Thickness of Geosynthetics. Annual Book of ASTM Standard. ASTM International: Philadelphia, PA, USA, 2019.

27. ASTM D4595-17; Standard Test Method for Tensile Properties of Geotextiles by the Wide-Width Strip Method. Annual Book of ASTM Standard. ASTM International: Philadelphia, PA, USA, 2017.

28. Al-Omari, R.R.; Fekheraldin, M.K. Measurement of tensile properties of geogrids. In Proceedings of the 2nd International Conference on Geotechnique, Construction Materials and Environment, Kuala Lumpur, Malaysia, 14-16 November 2012.

29. DH-S 205/2532The Standard of Subbase Course. Standards for Highway Construction; Department of Highway: Bangkok, Thailand, 1989. (In Thai)

30. Ruedeeviroj, S.; Duangdeun, P. Effect of gradation and fine particles in soil mass on engineering properties of lateritic soil mixed with fly ash. In Proceedings of the 10th National Convention on Civil Engineering, (In Thai). Pataya, Thailand, 2-4 May 2005.

31. AASHTO T 89; Standard Method of Test for Determining the Liquid Limit of Soils. American Association of State Highway and Transportation Officials (AASHTO): Washington, DC, USA, 2013.

32. AASHTO T 90; Standard Method of Test for Determining the Plastic Limit and Plasticity Index of Soils. American Association of State Highway and Transportation Officials (AASHTO): Washington, DC, USA, 2020.

33. ASTM D1883-99; Standard Test Method for CBR (California Bearing Ratio) of Laboratory-Compacted Soils. ASTM International: West Conshohocken, PA, USA, 1999.

34. ASTM D1557-07; Standard Test Methods for Laboratory Compaction Characteristics of Soil Using Modified Effort (56,000 ft-lbf $/ \mathrm{ft}^{3}$ $\left.\left(2700 \mathrm{kN}-\mathrm{m} / \mathrm{m}^{3}\right)\right)$. ASTM International: West Conshohocken, PA, USA, 2007.

35. Ahmed Kamel, M.; Chandra, S.; Kumar, P. Behaviour of subgrade soil reinforced with geogrid. Int. J. Pavement Eng. 2004, 5, 201-209. [CrossRef]

36. Nagrale, P.P.; Sawant, P.H.; Pusadkar, S.S. Laboratory investigation of reinforced sub grade soils. In Proceedings of the Indian Geotechnical Conference, Mumbai, India, 16-18 December 2010.

37. Saad, F.I.; Namir, G.A.; Dhuha, E.M. Effect of reinforcement on improve surface pavement for weak subgrade conditions. Int. J. Geomate 2016, 1, 2188-2193.

38. Udomchai, A.; Hoy, M.; Horpibulsuk, S.; Chinkulkijniwat, A.; Arulrajah, A. Failure of riverbank protection structure and remedial approach: A case study in Suraburi province, Thailand. Eng. Fail. Anal. 2018, 91, 243-254. [CrossRef]

39. Chaiyaput, S.; Suksawat, T.; Ayawanna, J. Evaluation of the road failure using resistivity and screw driving sounding testing techniques: A case study in Ang Thong province, Thailand. Eng. Fail. Anal. 2021, 121, 105171. [CrossRef]

40. Chaiyaput, S.; Sutti, N.; Suksawat, T.; Ayawanna, J. Electrical Resistivity Survey for Evaluating the Undrained Shear Strength of Soft Bangkok Clay at Some of the Canal-Side Road Investigation Sites. Bull. Eng. Geol. Environ. 2022, 81, 27. [CrossRef]

41. Chaiyaput, S.; Bergado, D.T. Reconfirmation of Skempton-Bjerrum 2D to 3D Settlement Conversion using FEM of Full Scale Embankments. Lowl. Technol. Int. 2018, 20,1-14.

42. Chaiyaput, S.; Bergado, D.T.; Artidteang, S. Measured and Simulated Results of a Kenaf Limited Life Geosynthetics (LLGs) Reinforced Test Embankment on Soft Clay. Geotext. Geomembr. 2014, 42, 39-47. [CrossRef]

43. PLAXIS Vietnam Seminar. Advanced Computational Geotechnics; PLAXIS Vietnam Seminar: Ho Chi Minh City, Vietnam, 2008.

44. Likitlersuang, S.; Surarak, C.; Wanatowski, D.; Oh, E.; Balasubramaniam, A. Finite element analysis of a deep excavation: A case study from the Bangkok MRT. Soils Found. 2013, 53, 756-773. [CrossRef]

45. Wulandari, P.S.; Tjandra, D. Analysis of geotextile reinforced road embankment using PLAXIS 2D. Procedia Eng. 2015, 125, 358-362. [CrossRef]

46. Vermeer, P.A.; Brinkgreve, R.B.J. Finite Element Code for Soil and Rock Analysis; A.A. Balkema: Rotterdam, The Netherland, 1995.

47. Brinkgreve, R.B.J.; Vermeer, P.A. PLAXIS-Finite Element Code for Soil and Rock Analyses; Plaxis BV. Balkema: Rotterdam, The Netherland, 1998. 